Acta Veterinaria (Beograd), Vol. 58, No. 1, 99-108, 2008.

DOI: $10.2298 / A V B 0801099 D$

UDK 619:616.314-089

\title{
THE EFFECT OF CAFFEIC ACID PHENETHYL ESTER ON HEALING CAPACITY AND REPAIR OF THE DENTIN-PULP COMPLEX: IN VIVO STUDY
}

\author{
DJURICA G*, DANILOVIĆ VESNA** and KRŠLJAK ELENA*** \\ *Department of Endodontics and Conservative Dentistry, Belgrade Dental School \\ **Department of Histology and Embryology Belgrade Dental School, \\ ***Department of Physiology, Belgrade Dental School
}

(Received 12. August 2007)

The aim of the present study was to investigate the effects of caffeic acid phenethyl ester (CAPE) on wound healing capacity and repair of the pulp dentin complex on an experimental model. Eight young male pigs were used in this study. Arteficially preformed pulp lesions were treated either with calcium hydroxide (control group) or with CAPE powder (experimental group). The material for histological analysis was 4 and 14 weeks after pulp capping. Results of the histological analysis revealed that inflammatory reactions occurred in both groups. In the control group inflammation could be scored as mild to moderate, with a tendency to decrease during the observed period, while in the experimental group it was scored as severe in most of the specimens. Dentin bridge formation and complete reparation of the dentin-pulp complex was observed in most of the specimens of the control group, while the repair process in the experimental group was characterized by fibrous tissue proliferation. In the experimental group severe haemorrhagia, tissue oedema and dentin resorption were also observed. Based on reported results it could be concluded that capping material containing CAPE could not enhance the repair of the dentin-pulp complex, and healing of the dentin-pulp complex was characterized by scar tissue formation, rather than dentin bridge formation.

Key words: dentin-pulp complex, repair, caffeic acid phenethyl ester (CAPE), histology

\section{INTRODUCTION}

Dentin has the potential of self-repair as mesenchymal progenitor cells within the pulp tissue can proliferate and differentiate into dentin-producing odontoblasts (Tziafas et al., 2000; Smith and Lesot, 2001; Gronthos et al., 2002). This multistep cascade of cellular events is coordinated by local growth factors that are produced in response to injury. Smith et al. (1995) proposed two definitions of the deposited dentin matrix: reactionary dentine defines dentine 
matrix secreted and laid down by surviving postmitotic odontoblast cells, while reparative dentine defines the dentine matrix secreted and laid down by a new generation of odontoblast-like cells in response to an appropriate stimulus, after death of the original postmitotic odontoblasts responsible for primary and physiological secondary dentine secretion.

A method of treatment, in which the exposed dental pulp is covered with a suitable material that protects the pulp from additional injury and permits healing and repair is known as direct pulp capping. The critical factors influencing the healing prognosis are the cytotoxic and biological properties of the capping material and its ability to control infection. It is widely accepted that the ultimate goal of the application of a capping material is to induce the dentinogenic potential of pulp cells (Schroeder, 1985; Stanley, 1989; Mjor et al., 1991). The dentinogenic potential can be induced directly as a specific biological effect of the capping material on pulpal cells, or indirectly as a part of the stereotypic wound healing mechanism in the traumatized pulp (Lesot et al., 1994).

Caffeic acid phenethyl ester (CAPE) is an active component of propolis, which is a resinous hive product collected by honeybees from various plant sources. Propolis is a popular folk medicine in various Asian, European and American countries possessing a broad spectrum of biological activities, including anticarcinogenic, anti-oxidant, anti-inflammatory, antibiotic, antifungal and antihepatotoxic effects (Banskota et al., 2001). It has been shown to be a pharmacologically safe compound, known to suppress lipid peroxidation and to stimulate the activity of antioxidant enzymes (Yagmurca et al., 2004). Caffeic acid phenethyl ester has been shown to exhibit anticancerogenic, anti-inflammatory and immunomodulatory activities in a broad spectrum of systems (Grunberger et al., 1988). At a concentration of $10 \mu \mathrm{mol} / \mathrm{L}$, CAPE completely blocks the generation of reactive oxygen species in human neutrophils and the xanthine/xanthine oxidase system (Nurettin et al., 2004). Recently, CAPE was investigated intensively in a number of animal models and various organs, including the kidney (Gurel et al., 2004), intestine (Koltuksuz et al., 1999), testis (Uz et al., 2002), spinal cord (Ilhan et al., 1999), hindlimbs (Calikoglu et al., 2003) and lungs (Ozyurt et al., 2004). It has been suggested that CAPE has protective effects against oxidative damage, which has been linked to its free radicalscavenging ability and antioxidant capacity (Calikoglu et al., 2003). It has also been reported that CAPE suppresses lipid peroxidation and inhibits lipoxygenase activity (Ozyurt et al., 2004).

Previous studies about CAPE effects on dental pulp tissue are controversial. Some authors have demonstrated that CAPE is toxic for dental pulp fibroblasts at $2 \mathrm{mg}$ and above (Al-Shaher et al., 2004), while others indicated that CAPE stimulates dental pulp collagen formation and reduces both pulp inflammation and degeneration (Sabir et al., 2005).

Therefore, the aim of the present study was to investigate the effects of CAPE on wound healing capacity and the repair of the pulp dentin complex on an experimental animal model. 


\section{MATERIAL AND METHODS}

\section{Experimental animals}

Eight healthy male pigs (Sus scropha domestica), weighting approximately 60 - $65 \mathrm{~kg}$ were used in this study. This in vivo study was carried out in accordance with the Ethic in Research Committee of the Faculty of Dentistry, Belgrade, regarding the care and use of animals for experimental procedures.

\section{Material used and methods}

The following materials were used:

- Life ${ }^{\circledR}$ Kerr Co., Orange County, CA, USA (commercial calcium hydroxide);

- $20 \mu \mathrm{mol} / \mathrm{mL}$ CAPE solution prepared in the Laboratory of Biochemistry, Faculty of Pharmacy, Belgrade, according to the standard method described by Grunberger et al. (1988), and pulverized on Silica gel (Merck, Darmstat, Germany).

\section{Experimental procedure}

The animals were anaesthetized by intramuscular administration of ketamine (Rotexmedica Trhttau Germany, $13 \mathrm{mg} / \mathrm{kg}$ body weight). The animals were placed on a surgical frame under aseptic conditions. After anesthesia and rubber-dam isolation, the teeth were cleaned with $70 \%$ ethanol. Class I cavities were prepared on the occlusal or vestibular surfaces of the first molars, using a round 0.5 bur at slow speed. Cavities were washed with copious sterile distilled water to remove debris created during cavity preparation. The pulp tissue was exposed using a sterile sharp right-angled probe. These procedures created a pulp exposure of uniform size. Hemorrhage was controlled with copious water irrigation. Pulpal lesions $(n=40)$ were treated either with calcium hydroxide (control, $n=20$ ), or with CAPE powder (experimental, $n=20$ ). $\mathrm{Ca}(\mathrm{OH})_{2}$ is commonly used as the control because it is the most well established material with dentinogenic properties (Schroeder, 1985; Cox and Bergenholz, 1986; D'Souza et al., 1995). Following application of the capping materials on the mechanically exposed pulps, the cavities were restored with amalgam. The animals were kept in cages and fed a stnadard diet and water. The animals were sacrificed with an overdose of Nembutal (Abbott Labs, Chicago USA) 4 and 14 weeks after surgery.

\section{Histological procedure}

After sacrification, the teeth were extracted, the roots removed, and the tissue was fixed in $10 \%$ buffered formalin solution for $48 \mathrm{~h}$. After demineralization of the teeth in 5\% trichloracetic acid for 40-50 days, the specimens were infiltrated with paraffin wax, and finally embedded in paraffin. Six $\mu \mathrm{m}$ thick serial sections were cut longitudinally and stained with haematoxylin and eosin and Gram technique for bacterial assessment. Histological analysis was accomplished using a light microscope (Carl Zeiss Inc., Oberkochen, Germany).

Histological analysis was preformed according to the folowing criteria: 
a. inflammatory reaction - chronic or acute and extension of the reaction. The intensities of these histological measures were classified into four grades: none, slight, moderate and severe, according to modified criteria (Stanley, 1968; Mjor and Trusted, 1972):

- none - the pulp contained a few, or none inflammatory cells;

- mild - the pulp had localized inflammatory lesions composed of polymorphonuclears or lymphocytes at the site of exposure;

- moderate - the pulp had inflammatory lesions involving more that one third of the pulp;

- severe - the whole pulp was infiltrated with inflammatory cells.

b. hard tissue bridge formation,

c. scar tissue formation,

d. vascular reaction: capillary dilatation and stasis,

g. presence of microorganisms.

\section{RESULTS}

Results of the histological analysis of the samples from the control group revealed that 4 weeks after treatment, necrosis was observed adjacent to the place of pulp exposure. The pulp tissue subjacent to the necrotic zone exhibited a mild to moderate inflammatory response associated with fibroblastic proliferation.

At 14 weeks, differentiation of cells resembling odontoblast-like cells was observed giving rise to a new layer of elongated cells that synthesized and deposited reparative dentine matrix (Figures 1 and 2).

This process resulted in the rise of the defined calcified barrier. The subjacent pulp tissue exhibited discrete mononuclear inflammatory cells infiltration and hyperaemic capillaries associated with pulp cell proliferation (Figure 3).

The more peripherial parts of the pulp tissue, far from the exposure region, exhibited normal histological characteristics. The histological evaluation of the specimens stained by Gram technique did not demonstrate bacteria at the cavity walls. Bacteria were observed in only one specimen, in which pulp breakdown occurred.

At short-term evaluation (4 weeks), the components of CAPE displaced into the pulp tissue caused a large area of pulpal degeneration and necrosis. The subjacent pulp tissue exhibited a moderate to severe inflammatory response related to congested blood vessels, intensive hemorrhagic areas, fibroblastic proliferation and dentinal resorption (Figures 4 and 5).

The increased permeability of the blood vessels, related to intense inflammation, resulted in the appearance of tissue edema in almost all specimens. No dentine matrix deposition was observed. In addition, no specimens exhibited bacterial growth at the cavity walls or into the pulp tissue. 
Acta Veterinaria (Beograd), Vol. 58. No. 1, 99-108, 2008.

Djurica $\mathrm{G}$ et al.: The effect of caffeic acid phenethyl ester on healing

capacity and repair of the dentin-pulp complex: in vivo study
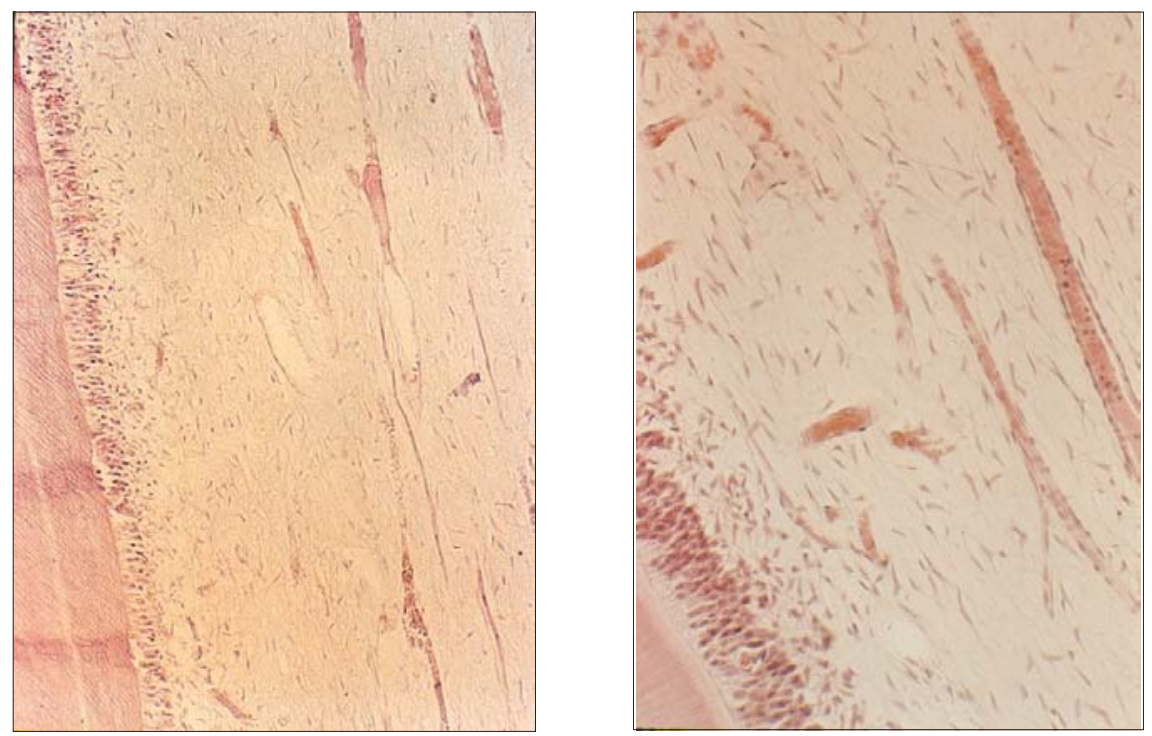

Figures 1 (HE, 100x). and 2 (HE, 250x). Microphotograph of the control specimen. 14 weeks after pulp capping, elongated cells, resembling odontoblast-like cells could be observed at the periphery. Secretory activity of these cells was uninterrupted and the region of predentin could be seen. Central parts of the pulp were characterized by the presence of dilated blood vessels, and mild infiltration with inflammatory cells

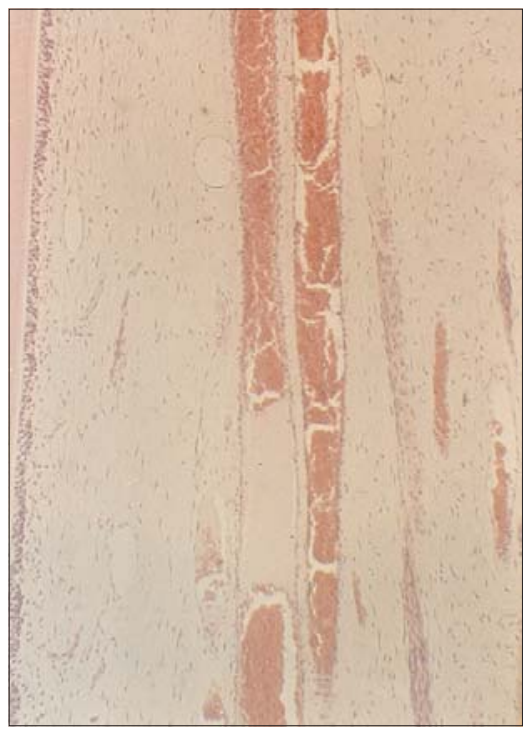

With time (14 weeks), the large zone of fibrous reparative matrix was observed in almost all the specimens of the experimental group. No odontoblast-like cell differentiation was observed adjacent to the place of mechanical injury of the pulp. The healing process resulted in the formation of an uncalcified barrier composed of connective tissue with irregular density. The subjacent pulp tissue exhibited intensive mononuclear inflammatory cells infiltration (Figure 6).

Figure 3 (HE, 100x). Microphotograph of the control specimen. 14 weeks after pulp capping with calcium hydroxide, central part of the dental pulp was characterized by discrete mononuclear infiltration and hyperaemic blood vessels 

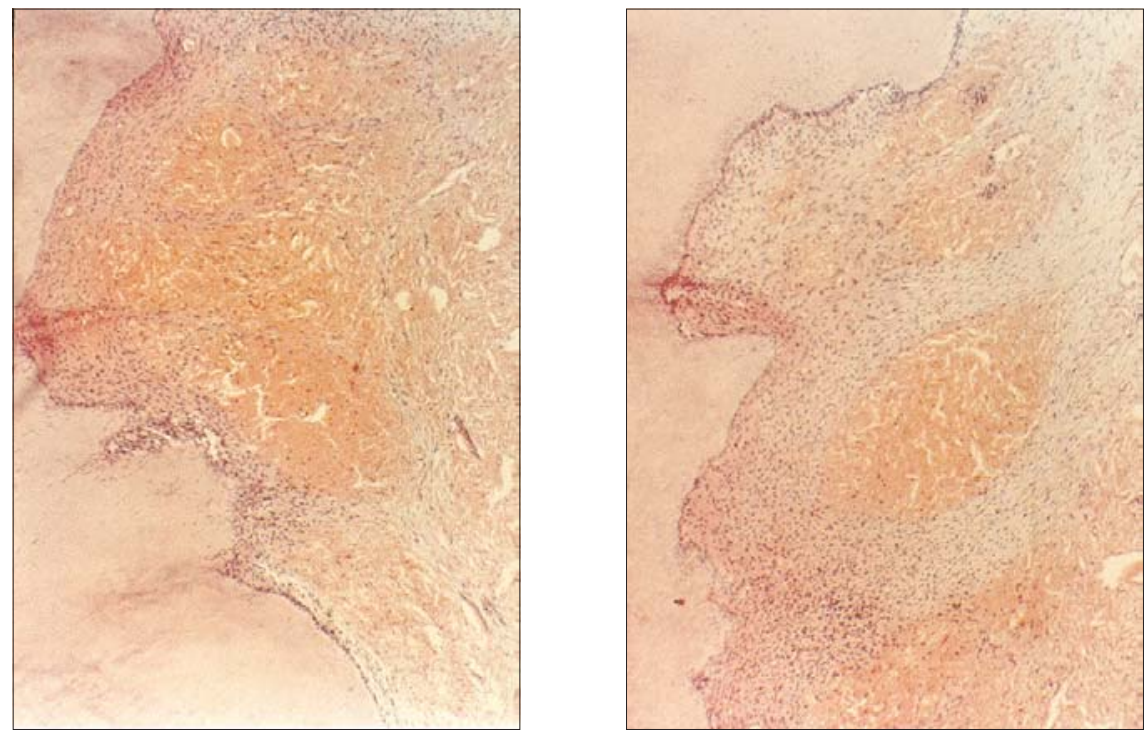

Figures $4(\mathrm{HE}, 100 \mathrm{x})$ and $5(\mathrm{HE}, 100 \mathrm{x})$. Microphotograph of the experimental specimen. 14 weeks after pulp capping with CAPE pulp tissue exhibited intense inflammatory response, congested blood vessels, intensive hemorrhagic areas and dentin resorption

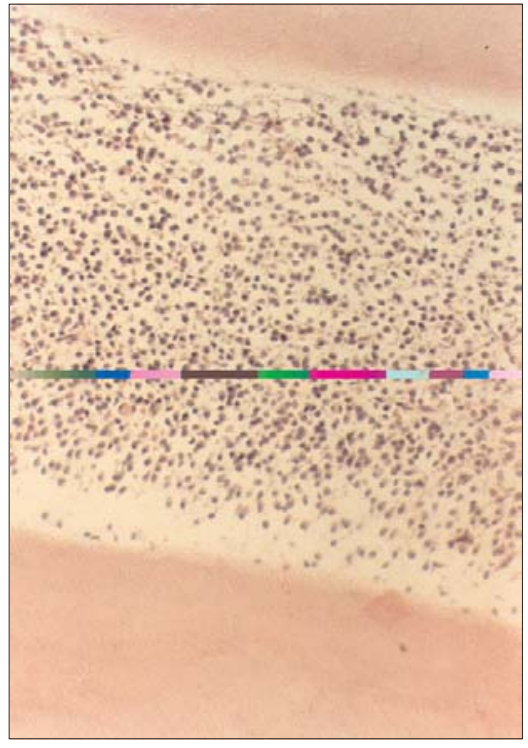

Primary odontoblasts at more peripherial parts of the dental pulp synthesized and deposited tubular reactive dentin in all analyzed samples. In one specimen, bacteria were observed at the lateral cavity walls. In this specimen, necrosis and zones of microabscesses were observed in the pulp tissue.

Figure 6 (HE, 250x). Microphotograph of the experimental specimen. 14 weeks after pulp capping with CAPE severe infiltration with inflammatory cells, mainly lymphocytes and plasma cells could be observed. The integrity of the pulp tissue was disturbed and the typical histological organization of the pulp into four zones could not be observed 


\section{DISCUSSION}

There is controversy concerning the value of using animals for evaluation of the biocompatibility of dental materials. Browne (1994), reported that previous tests evaluated specifically the biocompatibility of the material rather than the variables that may interfere with the outcome of the test. However, these tests remain the only acceptable manner of testing for biocompatibility of dental materials. Different animal species have been recommended for use in pulp or dentin tests in order to evaluate the biocompatibility of experimental dental materials (ISO DIS 7405 1994). This animal model is relatively inexpensive, easy to work with, allows the usage tests to be performed under laboratory conditions, and provides preliminary comparative evaluation of the biocompatibility of different dental materials. These investigations avoid exposing human patients to potentially harmful agents.

In the present investigation, teeth of young male pigs were used to evaluate the response of pulps previously mechanically exposed and capped with CAPE.

The present study showed that direct pulp capping with calcium hydroxide and CAPE pulver stimulated an inflammatory response as early as 4 weeks after treatment, with markable differences between these two groups. These findings are in disagreement with the recent results of Sabir et al. (2005), who reported suppression of dental pulp inflammation in a group treated with CAPE. The present results are surprising, since CAPE is known to have anti-inflammatory properties, perhaps via suppression of immune cell activation, macrophagederived nitric oxide, cytokine production and neutrophil activation (Burdock, 1998).

An important observation was the absence of dentinal bridge formation in all experimental samples. Dentin formation following pulp capping is known to involve differentiation of odontoblast-like cells that form reparative dentin, and the biosynthetic activity of surrounding primary odontoblasts. Both phenomena require interaction between the extracellular matrix and growth factors, such as transforming growth factor (TGF)- $\beta 1$, which is known to be important for the odontoblast-like cell differentiation (Tziafas, 2004). Since it was previously reported that CAPE is capable of stimulating the production of TGF- $\beta 1$ (Ansorge et al., 2003) and the synthesis of collagen by dental pulp cells (Sabir, 2005), it stays unclear which mechanism is involved in the failure of formation of the calcified barrier and complete closure of the pulp chamber. It remains to be further clarified the reason why stimulatory effects of CAPE on reparative dentinogenesis could not occur through this pathway.

The results of our study revealed that bacteria have not been identified in dental pulp samples. This observation may be explained by the aseptic conditions during the experimental procedure and perhaps by the antibacterial effect of CAPE (Aga et al., 1994). Although the absence of infection is the crucial for the healing process, results of the histological analysis of the samples treated with CAPE revealed that complete repair occurred in only a few samples. Remaining samples were characterized by the presence of dilated blood vessels, stasis, tissue oedema and hemorrhagia. This can be explained partially as the result of 
severe inflammation, but more probably as a sequel of endothelial cell damage cased by highly cytotoxic effects of CAPE to a variety of malignant solid tumor and leukemia cell lines in vitro, and to solid tumor grafts in vivo, reported in recent papers (lqbal et al., 2003a, 2003b).

\section{CONCLUSIONS}

In conslusion, the present study has shown that caffeic acid phenethyl ester (CAPE) used as capping material has not inhibited dental pulp inflammatory responses in experimental animals. However, pulp inflammation was evident at week 4 and 14. Dentinal bridge formation and complete closure of the pulp chamber was detected in the control group treated with calcium hydroxide, but not in the CAPE treated experimental group. Therefore, the present results obtained in pigs suggest that CAPE could not enhance healing and repair of the dentin-pulp complex.

Address for correspondence:

Assistant professor dr Grga Djurica

Department of Endodontics and Conservative Dentistry

Belgrade Dental School

Rankeova 4, Belgrade, Serbia

e-mail: Đurica.Grga@stomf.bg.ac.yu

\section{REFERENCES}

1. Aga H, Shibuya T, Sugimoto T, Kurimoto M, Nakajima $S$, 1994, Isolation and identification of antimicrobial compounds in Brazilian propolis, Biosci Biotech Biochem, 58, 945-56.

2. Al-Shaher A, Wallace J, Agarwal S, Bretz W, Baugh D, 2004, Effects of propolis on human fibroblasts from the pulp and periodontal ligament, $J$ Endodont, 30, 359-41.

3. Ansorge A, Reinhold D, Lendckel U, 2003, Propolis and some of its constituents down regulate DNA synthesis and inflammatory cytokine production, but induce TGF-beta1 production of human immune cells, $Z$ Naturforsch, 58, 580-9.

4. Banskota AH, Tezuka Y, Kadota S, 2001, Recent progression pharmacological research of propolis, Phytother Res, 15, 561-71.

5. Browne RM, 1994, Animal test for biocompatibility of dental materials - relevance, advantages and limitations, J Dentistry 22, 21-4.

6. Burdock GA, 1998, Review of the biological properties and toxiticity of bee propolis, Food Chem Toxicol, 36, 347-63.

7. Calikoglu M, Tamer L, Sucu N, 2003, The effects of caffeic acid phenethyl ester on tissue damage in lung after hindlimb ischemia-reperfusion, Pharmacol Res, 48, 397-403.

8.Cox CF, Bergenholt G, 1986, Healing sequence in capped inflamed pulps of Rhesus monkeys (Macaca mulatta), Inter Endod J, 19, 113-20.

9. D'Souza RN, Bachman T, Baumgardner KR, Butler WT, Litz M, 1995, Characterization of cellular responses involved in reparative dentinogenesis in rat molars, $J$ Dent Res, 74, 702-9.

10. Gronthos S, Brahim J, Li W, 2002, Stem cell properties of human dental pulp stem cells. J Denl Res 81, 531-5.

11. Grunberger D, Banerjee R, Eisinger K, 1988, Preferential cytotoxicity on tumor cells by caffeic acid phenethyl ester isolated from propolis. Experientia, 44, 230-2. 
12. Gurel A, Armutcu F, Sahin S, 2004, Protective role of á-tocopherol and caffeic acid phenethyl ester on ischemia-reperfusion injury via nitric oxide and myeloperoxidase in rat kidneys, Clin Chim Acta, 339, 33-41.

13. Ilhan A, Koltuksuz U, Ozen S, Uz E, Ciralik H, Akyol O, 1999, The effects of caffeic acid phenethyl ester (CAPE) on spinal cord ischemia/reperfusion injury in rabbits, Eur J Cardiothorac Surg, 16, 458-63.

14. Iqbal M, Okazaki Y, Okada S, 2003a, In vitro curcumin modulates ferric nitrilotriacetate (Fe-NTA) and hydrogen peroxide (H2O2)-induced peroxidation of microsomal membrane lipids and DNA damage, Teratogen Carcinogen Mutagen, 23, 151-6.

15. Iqbal M, Okazaki Y, Okada S, 2003b, Cell Growth Inhibitory Effect of Cinnamic Acid Derivatives from Propolis on Human Tumor Cell Lines, Biol Pharmac Bull, 26, 1057-65.

16. ISO DIS 7405, 1994, Preclinical Evaluation of Biocompatibility of Medical Devices Used in Dentistry.

17. Koltuksuz U, Ozen $S, U z E, 1999$, Caffeic acid phenethyl ester prevents intestinal reperfusion injury in rats, $J$ Pediatr Surg, 34, 1458-62.

18. Lesot H, Smith AJ, Tziafas D, Begue-Kirn C, Cassidy N, Ruch JV, 1994, Biologically active molecules and dental tissue repair: a comparative review of reactionary and reparative dentinogenesis with the induction of differentiation in vitro, Cells Mater, 4, 199-218.

19. Mjör IA, Dahl E, Cox CF, 1991, Healing of pulp exposures: an ultrastructural study, J Oral Pathol Med, 20, 496-501.

20. Mjör IAN, Trusted L, 1972, Experimentally induced pulpitis. Oral Surg Oral Med Oral Pathol, 3, 1028.

21. Nurettin Aydogdu, Gulizar Atmaca, Omer Yalcin, Kadir Batcioglu, Kadir Kaymak, 2004, Effects of caffeic acid phenethyl ester on glycerol-induced acute renal failure in rats, Clin Experim Pharmacol Physiol, 31, 9, 575-9.

22. Ozyurt H, Sogut S, Yildirim Z, 2004, Inhibitory effect of caffeic acid phenethyl ester on bleomycineinduced lung fibrosis in rats, Clin Chim Acta, 339, 65-75.

23. Sabir A, Tabbu CR, Augustino P, Sosrosenso W, 2005, Histological analysis of rat dental pulp tissue capped with propolis, J Oral Sci, 47,135-8

24. Schroeder U, 1985, Effects of calcium hydroxide-containing pulp capping agents on pulp cell migration, proliferation and differentiation, J Dent Res, 64, 541-8.

25. Smith AJ, Cassidy N, Perry H, Bègue-Kirn C, Ruch JV, Lesot H, 1995, Reactionary dentinogenesis, Int J Devel Biol, 39, 273-80.

26. Smith AJ, Lesot H, 2001, Induction and regulation of crown dentinogenesis: embryonic events as a template for dental tissue repair? Crit Rev Oral Biol Med, 12, 425-37.

27. Stanley HR, 1968, Design for a human pulp study. Part II, Oral Surg, Oral Med Oral Pathol, 25, 75664.

28. Stanley HR, 1989, Pulp capping: conserving the dental pulp- Can it be done? Is it worth it? Oral Surg Oral Med Oral Pathol, 68, 628-39.

29. Tziafas $D, 2004$, The future role of molecular approach to pulp-dentinal regeneration, Caries Res, 38, 314-20.

30. Tziafas D, Smith AJ, Lesot H, 2000, Designing new treatment strategies in vital pulp therapy, J Dent, 28, 77-92.

31. Uz E, Sogut S, Sahin S, 2002, The protective role of caffeic acid phenethyl ester (CAPE) on testicular tissue after testicular torsion and detorsion, World J Urol, 20, 264-70.

32. Yagmurca M, Erdogan H, Iraz M, Songur A, Ucar M, Fadillioglu E, 2004, Caffeic acid phenethyl ester as a protective agent against doxorubicin nephrotoxicity in rats, Clin Chim Acta, 348, 27-34. 


\title{
EFEKAT FENETIL ESTRA KAFEINSKE KISELINE NA MOGUĆNOST ZARASTANJA I REPARACIJU DENTINSKO-PULPNOG KOMPLEKSA: STUDIJA IN VIVO
}

\author{
DJURICA G, DANILOVIĆ VESNA i KRŠLJAK ELENA
}

\begin{abstract}
SADRŽAJ
Cilj rad je bio da se ispita efekat fenetil estra kafeinske kiseline na proces zarastanja rane i reparaciju dentinsko-pulpnog kompleksa. Istraživanje je izvršeno na 8 svinja muškog pola t.m. $60-65 \mathrm{~kg}$. Njima je arteficijelno napravljena lezija u dentinsko-pulpnom kompleksu, koja je tretirana kalcijum hidroksidom (kontrolna grupa) ili fenetil estrom kafeinske kiseline (eksperimentalna grupa). Materijal za histološku analizu uzet je 4 i 14 nedelja nakon prekrivanja pulpe. Rezultati histološke analize su ukazali da se u obe grupe uzoraka pojavila zapaljenska reakcija. U kontrolnoj grupi, ona je ocenjena kao blaga do umerena, sa tendencijom smanjivanja tokom observacionog perioda, dok je u eksperimentalnoj grupi, u najvećem broju uzoraka ona ocenjena kao teška. Kompletna reparacija dentinsko-pulpnog kompleksa sa stvaranjem dentinskog mostića uočena je samo u kontrolnoj grupi, dok je u eksperimentalnoj, zarastanje bilo karakterisano vezivno tkivnom proliferacijom. U velikom broju uzoraka eksperimentalne grupe uočeni su znaci krvarenja, edema i resorpcije dentina. Na osnovu rezultata dobijenih u ovoj studiji može se reći da fenetil estar kafeinske kiseline ne podstiče reparativne procese u dentinsko-pulpnom kompleksu, tako da proces zarastanja rane nije bio praćen formiranjem reparativnog dentina već vezivno-tkivnog ožiljka.
\end{abstract}

